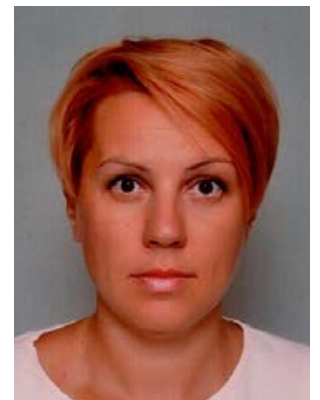

Olena $\mathbf{M}$. Hanoshenko, Ганошенко Олена Миколаївна

УДК 662.7-028.82: 629.33.063.7-027.32

\title{
ENVIRONMENTALLY SAFE ALTERNATIVE PROCESS FOR PRODUCING FUEL FROM WASTE AUTOMOBILE OIL FILTERS
}

\section{ЕКОЛОГІЧНО БЕЗПЕЧНИЙ СПОСІБ ОТРИМАННЯ АЛЬТЕРНАТИВНОГО ПАЛИВА ІЗ ВІДПРАЦЬОВАНИХ АВТОМОБІЛЬНИХ МАСТИЛЬНИХ ФІЛЬТРІВ}

\author{
DOI https:// doi.org/10.15589/smi2020.1(13).6
}

Olena M. Hanoshenko

Ганошенко Олена Миколаївна, канд. техн. наук, ст. викладач elena.ganoshenko26@gmail.com ORCID: 0000-0002-9818-4084

\section{National University "Yuri Kondratyuk Poltava Polytechnic", Poltava Наиіональний університет «Полтавська політехніка імені Юрія Кондратюка», м. Полтава}

\begin{abstract}
The policies of many countries around the world are aimed at the rational management of waste in order to reduce the negative impact on the environment and save natural resources. The amount of the formation of used car filters, due to the need for frequent replacement and the number of cars, is very large. And the component composition indicates the possibility of obtaining a high environmental and economic effect.

The research conductions of the use of filter paper of used automotive oil filters as an alternative fuel for local heat generating plants, which allows to increase the level of environmental safety by reducing the ingress of hazardous waste into the environment. The analysis of the existing heat supply system of the building of the plant of PJSC "NDI KOLAN" in Poltava is performed, possible variants of heat supply are considered, and also the technical and economic estimation of the accepted decisions are executed. The energy potential of used car filters is determined.

The paper part of the new "KOLAN" type filters is $18-36 \mathrm{~g}$. Based on the planned level of productivity of the technology of recycling of used automobile oil filters in the process of utilization, from 15060 to $90360 \mathrm{~kg}$ of oiled filter paper are formed. The specific heat of combustion of oiled filter paper which is $6819.6 \mathrm{kcal} / \mathrm{kg}$ is determined. When converted to conventional fuel, it will be 88.03 tons per year. In terms of gas fuel, this saves $77027 \mathrm{~m}^{3}$ of gas per year, and thus we get annual savings of 931.3 thousand UAH.

The exploitation of filter paper of used automobile oil filters as an alternative fuel for local heat generating plants has been further developed, which allows to increase the level of environmental safety of the atmosphere by reducing the amount of pollutants in flue gases. The results of the work were transferred to PJSC "NDI KOLAN" for industrial use in the modernization of the existing heat supply system at heat generating units.
\end{abstract}

Key words: anthropogenic impact, recycling, waste automobile filters, filter paper, waste oils, products of combustion, environmental safety.

Анотація. Більшість країн світу ведуть політику, спрямовану на раціональне поводження з відходами, що зменшить негативний вплив на довкілля та використання природних ресурсів. Кількість утворених відпрацьованих автомобільних фільтрів у зв'язку з необхідністю їх частої заміни дуже велика, а компонентний склад свідчить про можливість отримання високого екологічного й економічного ефекту.

У роботі проведено дослідження використання як альтернативного палива для локальних теплогенеруючих установок фільтрувального паперу відпрацьованих автомобільних мастильних фільтрів. При зменшенні потрапляння таких небезпечних відходів у навколишнє середовище підвищиться рівень екологічної безпеки довкілля. Виконаний аналіз системи теплопостачання будівлі заводу ПАТ «НДІ КОЛАН» у м. Полтава, розглянуті інші можливі варіанти та виконане техніко-економічне оцінювання прийнятих рішень. Визначений енергетичний потенціал відпрацьованих автомобільних фільтрів. Паперова частина нових фільтрів типу «КОЛАН» становить 18-36 г. У процесі утилізації відповідно до запланованого рівня продуктивності технології рециклінгу відпрацьованих автомобільних мастильних фільтрів утворюється від 15060 до 90360 кг промасленого фільтрувального паперу. Визначена питома теплота згоряння промасленого фільтрувального паперу, яка становить 6819,6 ккал/кг. При перерахунку на умовне паливо це становитиме 88,03 тонни за рік. У перерахунку на газове паливо це дозволяє 
зберегти 77027 м³ газу за рік, а отже, отримуємо річну економію у розмірі 931,3 тис. грн.

Розвивається використання як альтернативного палива для локальних теплогенеруючих установок фільтрувального паперу відпрацьованих автомобільних мастильних фільтрів, що дозволить підвищити рівень екологічної безпеки атмосфери за рахунок зменшення кількості забруднювальних речовин у димових газах. Результати роботи передані до ПАТ «НДІ КОЛАН» для промислового використання при модернізації наявної системи теплопостачання на теплогенеруючих установках.

Ключові слова: техногенне навантаження, утилізація, відпрацьовані автомобільні фільтри, фільтрувальний папір, відпрацьовані мастила, продукти горіння, екологічна безпека.

\section{References}

[1] Derzhavnyy klasyfikator Ukrainy. [State Classifier of Ukraine]. Klasyfikator vidhodiv DK 005-96 [The classifier from DK 005-96], zatverdzhenyy nakazom Derzhstandartu Ukrainy 29.02.1996 № 89 [Approved by the order of the State Standard of Ukraine 29.02.1996 № 89].

[2] Ganoshenko O.M., Golik Y.S., Koltunov G.A. (2016). Resyrsnyy potentsial otrabotannyh avtomobilnyh filtrov [Resource potential of used automotive filters]. Sciences of Europe. Vol 2. № 5 (5). P. 72-77.

[3] Katrushov O.V., Kostenko V.O., Batuhina I.V., Solovyova N.V., Filatova V.L. (2009). Patohenna diya vidpratsiovannyh motornyh masel: nedootsinena nebezpeka [Pathogenic effects of used motor oils: underestimated danger]. Aktualni problemy suchasnoi medytsyny: Visn. Ukrainskoi med. stomatal. akademiyi. T. 9. № 3. P. 188-193.

[4] Ganoshenko O.M., Golik Y.S. (2018). Analiz problem utvorennia ta utylizatsiyi vidhodiv avtotransportnoho complexu [Analysis of the problem of waste generation and utilization of the motor transport complex]. Ekologichni nauky. № 2 (21). P. 40-46.

[5] TOV "Poltavahaz bud" informuie spozhuvachiv shchodo taryfiv ta tsiny na prurodnui haz dlia promyslovyh spozyvachiv ta biudzhentyh orhanizatsiy z 1 kvintia 2019 roku [informs natural gas consumers about tariffs and prices for natural gas for industrial consumers and budgetary organizations from April 1, 2019.]. URL: http://poltavagazzbut. com.ua/?page_id=28.

Постановка проблеми. Світовий досвід свідчить про те, що політика більшості країн спрямована на раціональне поводження з відходами для зниження негативного впливу на навколишнє середовище та зменшення використання природних ресурсів. Першим кроком до раціонального поводження з відпрацьованими мастильними фільтрами є їхнє правильне збирання. Необхідно знати, як потрібно правильно утилізувати відпрацьовані фільтри, тому запроваджуються різні санкції та стимули - як для підприємств, так і для громадян - для урегулювання цього питання.

Варто зазначити, що одним із можливих варіантів утилізації відходів є використання замкнутого циклу виробництва. Тому за сучасних умов перероблення відходів на спеціалізованих підприємствах вважається найбільш перспективним, логічним і доступним способом їхньої утилізації.

ПАТ «НДІ КОЛАН» шляхом повної утилізації складників запобігає можливому потраплянню небезпечного відходу у довкілля, відпрацьованих автомобільних мастильних фільтрів із застосуванням сучасних технологій. Використання як альтернативного палива для локальних теплогенеруючих установок вилученого фільтрувального паперу дозволить за рахунок зменшення кількості забруднювальних речовин у димових газах підвищити рівень екологічної безпеки атмосфери.

Аналіз останніх досліджень і публікацій. Технологічні процеси утилізації відпрацьованих автомобільних мастильних фільтрів, які використовують корпорації різних країн світу, мають певні відмінності, що залежить від обсягів виробництва, тех- нічних та економічних можливостей підприємств, нормативно-правової бази держав, на території яких здійснюється їхня діяльність. Будь-який процес утилізації відпрацьованого автомобільного мастильного фільтра базується на видаленні та зборі мастила. Коли відбувається заміна автомобільного фільтра, мастило 3 нього необхідно зливати гарячим, тобто відразу після зупинки роботи двигуна, завдяки чому в ньому залишається його менша кількість. Відпрацьовані автомобільні мастильні фільтри необхідно піддавати своєчасній заміні з обов'язковими умовами: повторним використанням ресурсоцінних компонентів, а саме рециклінгом і знешкодженням небезпечних елементів із подальшою їхньою утилізацією (спалюванням, похованням).

Пошук менш енергоємних і більш ефективних систем теплопостачання будівель є одним із важливих напрямів у галузі енергозбереження.

Виокремлення не вирішених раніше частин загальної проблеми. 3 погляду природоохоронної та ресурсозберігаючої діяльності технології повторного використання автомобільних шин, утилізації акумуляторів, моторних мастил становлять значний екологічний та економічний інтерес. У зв'язку 3 тим, що відпрацьовані автомобільні фільтри як промислові відходи віднесені до 3 класу небезпеки, потрібно більш детально їх розглянути. Відповідно до Державного класифікатора відходів ДК 005-96 вони становлять таку групу: 7730.3.1.05 - Матеріали фільтрувальні зіпсовані, відпрацьовані чи забруднені, що $€$ абсолютно неможливими для їх поховання. Відпрацьовані автомобільні фільтри - потенційні ресурсоцінні відходи, які вимагають обов'язкової утилізації 
(рециклінгу) та повторного використання їхніх компонентів [1].

Найбільш небезпечним відпрацьованим автомобільним фільтром є мастильний через вміст відпрацьованого автомобільного мастила. Такий тип відходів віднесений до 3 класу небезпеки, у разі потрапляння у довкілля забруднює повітря, грунт, поверхневі та підземні води. Особливо небезпечними $\epsilon$ синтетичне та напівсинтетичне мастила. Тому актуальною проблемою є утилізація та перероблення автомобільних мастильних фільтрів.

Мета дослідження. Мета - утилізація відпрацьованих автомобільних масляних фільтрів екологічно безпечним способом 3 отриманням альтернативної енергії для зменшення навантаження на довкілля та ресурсозбереження, що дасть значний екологічний та економічний ефекти.

Методи, об'єкт та предмет дослідження. Застосування системного підходу до оцінювання техногенного навантаження відходів автотранспорту на екосистему; ресурсозберігаючий ефект від утилізації відпрацьованого фільтрувального паперу; спосіб отримання альтернативного палива.

Основний матеріал (результати). Дослідження відпрацьованих мастил показали, що вони містять: продукти зносу; залишки присадок; продукти згоряння (поліциклічні ароматичні вуглеводні); важкі метали (барій, хром, цинк тощо); дегідровані компоненти мастила [2].

Всі перераховані вище речовини є шкідливими для людського організму та навколишнього середовища. У разі попадання у грунтові води або грунт відпрацьовані мастила можуть токсично впливати на людей і тварин. Тому їх збирання та подальше оброблення є обов'язковим. Саме такий підхід дозволяє виключити можливість потрапляння токсинів у навколишнє середовище [3].

Обов'язковими умовами своєчасної заміни відпрацьованих автомобільних мастильних фільтрів $є$ повторне використання ресурсоцінних компонентів, рециклінг і знешкодження небезпечних елементів із подальшою їх утилізацією (спалюванням, похованням). Обсяги утворення відпрацьованих автомобільних фільтрів у зв'язку з необхідністю їх частої заміни та кількістю автомобілів дуже великі, а можливість отримання високого екологічного й економічного ефекту підтверджена дослідженнями компонентного складу такого типу відходів. Новітні технології повторного використання й утилізації промислових відходів стають необхідною частиною поліпшення навколишнього середовища.

Експериментальне визначення теплоти згоряння палива (відпрацьованого паперу автомобільних масляних фільтрів) за допомогою калориметра дасть можливість оцінити енергетичний потенціал. Горючими елементами у паливі є вуглець С, водень $\mathrm{H}$ i летюча горюча сірка $\mathrm{S}$. Вуглець - основний носій теплоти. Водень - другий найбільш важливий елемент палива. Сірка при згорянні виділяє велику кількість теплоти, натомість сірчисті з'єднання підвищують корозію металевих деталей, а у навколишньому середовищі сприяють утворенню кислотних опадів.

Теплоту згоряння палива (при постійному об'ємі) $\mathrm{Q}_{6}$ з досліду, проведеного у калориметрі, обчислюють за формулою:

$$
\mathrm{Q}=\mathrm{W} \cdot \Delta \mathrm{T}
$$

де $\Delta \mathrm{T}$ - зміна температури калориметричної системи, К;

$\mathrm{W}$ - теплоємність системи або енергетичний еквівалент калориметра.

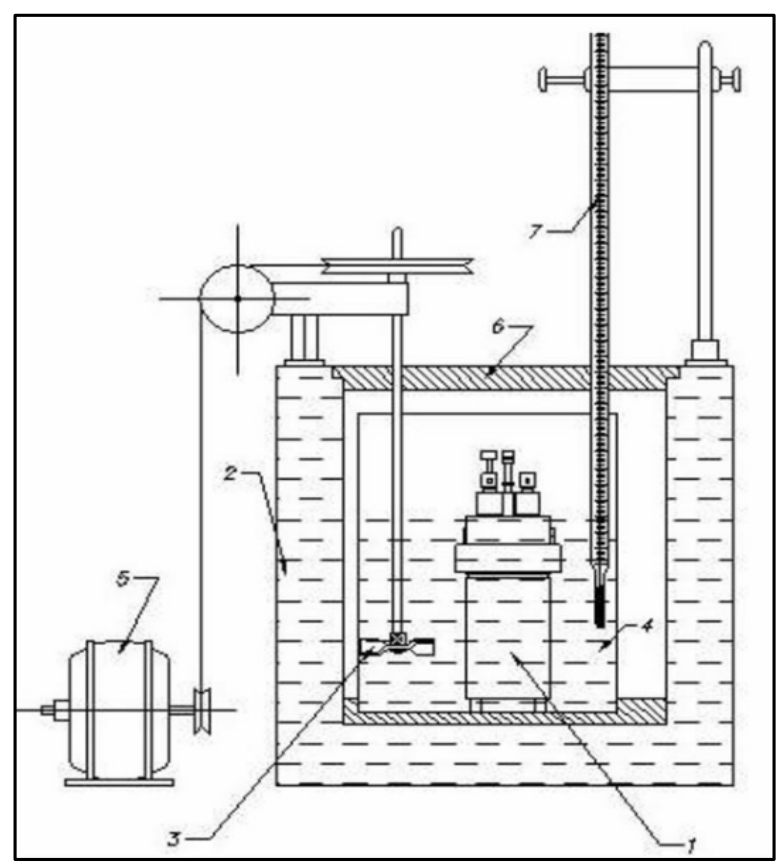

Рис. 1. Схема експериментальної установки калориметрична бомба

1 - калориметрична бомба; 2 - оболонка калориметра;

3 -мішалка; 4 -латунна посудина з водою; 5 -

електричний двигун; 6-кришка; 7-ртутний термометр

$\Delta \mathrm{T}$, яку називають істинною змінною температури, не можна виміряти безпосередньо, оскільки на цю величину впливає теплообмін калориметричної системи з навколишнім середовищем, а також побічні джерела енергії - тертя мішалки калориметра, енергія струму термометра опору і т. д.

Тому у досліді безпосередньо вимірюється зміна температури $\Delta T^{\prime}$, яка завжди відрізняється від істинної. Для отримання справжньої зміни температури необхідно ввести поправку на теплообмін і на побічні ефекти. Таким чином, за відсутності побічних теплових ефектів:

$$
\Delta \mathrm{T}=\Delta \mathrm{T}^{\prime}-\delta
$$

де $\delta$ - поправка на теплообмін.

Калориметричну бомбу перед використанням калібрують і визначають ㄲï енергетичний еквівалент. 
Енергетичний еквівалент бомбових калориметрів (W) визначають шляхом спалювання високочистої бензойної кислоти, що $є$ вихідною еталонною речовиною. Енергія згоряння іï встановлена як фізична константа за певних так званих стандартних бомбових умов:

1) реакція згоряння зразка протікає при постійному об'ємі за ізотермічних умов при 298,15 К;

2) початковий тиск чистого кисню у бомбі, виміряний при 298,15 К, має становити 3,04 МПа (30 атм);

3) маса зразка бензойної кислоти береться 3 розрахунку 3 г на 1 дм³ об'єму бомби;

4) кількість води, що вводиться перед дослідом у бомбу (для насичення водяними парами ії внутрішнього простору), береться із розрахунку 3 г на 1 дм об'єму бомби.

За цих умов енергія згоряння бензойної кислоти прийнята рівною (26 434,4 \pm 0,6) кДж/кг. На практиці часто можуть бути відхилення від цих умов. Тому енергія згоряння за фактичних бомбових умов відрізняється від енергії згоряння за стандартних бомбових умов.

При спалюванні у калориметричній бомбі точно зваженої наважки $(1,00 \pm 0,01$ г) бензойної кислоти визначено чисельне значення $\mathrm{W}$, повідомляючи калориметру відому кількість енергії та вимірюючи викликаний цим підйом температури. Енергетичний еквівалент розраховано за формулою:

$$
W=\frac{m_{1} \cdot Q_{6 . \kappa .}}{\Delta T_{1}}
$$

де $m_{1}$ - маса наважки еталонної бензойної кислоти; 1,1833 г;

$Q_{\text {б.к. }}-$ питома теплота згоряння зразка бензойної кислоти; 26467 кДж/кг;

$\Delta T_{1}$ - підйом температури у досліді з бензойною кислотою; 3,036 К.

При оцінюванні калорійності зразка досліджуваного палива проводиться порівняння теплоти згоряння палива та бензойної кислоти:

$$
Q_{\text {палива }}=\frac{W \cdot \Delta T_{2}}{m_{2}}=\frac{m_{1} \cdot \Delta T_{2}}{m_{2} \cdot \Delta T_{1}} \cdot Q_{\sigma . к .}
$$

де $Q_{\text {палива }}$ - питома теплота згоряння досліджуваного палива, кДж/кг;

$m_{2}$ - маса наважки досліджуваного палива, г;

$\Delta T_{2}-$ підйом температури у досліді з паливом, К.

Визначення питомої теплоти згорання відпрацьованого фільтрувального паперу проведено у калориметричній бомбі за двома наважками, а за остаточний результат прийнято середнє із двох значень.

$$
Q_{\text {паперу }}=28557,9 \text { кДж/кг }=6819,6 \text { ккал/кг }
$$

Далі у розрахунках величину теплоти згорання відпрацьованого фільтрувального паперу приймаємо $Q_{\text {паперу }}=6819,6$ ккал/кг [4].

Обговорення отриманих результатів. Експериментальні випробування екологічно безпечного способу отримання альтернативного палива було проведено на базі ПАТ «НДІ КОЛАН». За умови, що паперова частина нових фільтрів типу «КОЛАН» дорівнює 18-36 г, запланований рівень продуктивності технології рециклінгу відпрацьованих автомобільних мастильних фільтрів становить:

- $\quad$ мінімальний - 1000 шт. на добу або 251 тис. шт. фільтрів за рік;

- $\quad$ максимальний - 3000 шт. на добу або 753 тис. шт. за рік (із розрахунку 251 робочий день на рік).

Кількість відпрацьованого фільтрувального паперу, що утворюється, становить:

$\min =60 \cdot 1000 \cdot 251 / 1000=15060$ кг $/$ рік;

$\max =120 \cdot 3000 \cdot 251 / 1000=90360 \kappa г /$ рік.

У процесі утилізації фільтрів за рік утворюється від 15060 до 90360 кг промасленого фільтрувального паперу. Визначена питома теплота згоряння промасленого фільтрувального паперу - 6 819,6 ккал/кг. У перерахунку на умовне паливо - 7000 ккал/кг - це становитиме:

$m=90360 \cdot 6819,6 / 7000=88031$ кг умовного палива, 88,03 тонни за рік.

У перерахунку на газове паливо (теплотворна здатність 8000 ккал/ $\mathbf{m}^{3}$ ) це дозволяє зберегти:

$V=90360 \cdot 6819,6 / 8000=77027$ м $^{3}$ газу за рік.

Станом на 1 січня 2019 р. тариф природного газу для промислових підприємств становив 12090 грн за $1000 \mathrm{~m}^{3}$ [5], а отже, отримуємо річну економію у розмірі:

$E=77,03 \cdot 12090=931310$ грн.

Використання фільтрувального паперу із залишками відпрацьованого моторного мастила як альтернативного палива зменшить щорічні витрати підприємства для опалення на 931,3 тис. грн.

Висновки. Встановлено, що обсяги утворення відпрацьованих автомобільних фільтрів у зв'язку 3 необхідністю їх частої заміни та кількістю автомобілів дуже великі. Отримання високого екологічного й економічного ефекту підтверджена дослідженнями компонентного складу такого типу відходів. Новітні технології повторного використання й утилізації промислових відходів стають необхідною частиною поліпшення навколишнього середовища.

Використання фільтрувального паперу із залишками відпрацьованого моторного мастила як альтернативного палива зменшить щорічні витрати для опалення підприємства ПАТ «НДІ КОЛАН» за рахунок використання газового палива на 931,3 тис. грн.

\section{Список літератури:}

[1] Державний класифікатор України. Класифікатор відходів ДК 005-96, затверджений наказом Держстандарту України 29 лютого 1996 р. № 89.

[2] Ганошенко О.М., Голик Ю.С., Колтунов Г.А. Ресурсный потенциал отработанных автомобильных фильтров. Sciences of Europe. 2016. Vol 2. № 5 (5). С. 72-77. 
[3] Катрушов О.В, Костенко В.О., Батухіна І.В., Соловйова Н.В., Філатова В.Л. Патогенна дія відпрацьованих моторних масел: недооцінена небезпека. Актуальні проблеми сучасної медицини. Вісник Української медичної стоматологічної академії. 2009. Т. 9. № 3. С. 188-193.

[4] Ганошенко О.М., Голік Ю.С. Аналіз проблеми утворення та утилізації відходів автотранспортного комплексу. Екологічні науки. 2018. № 2 (21). С. 40-46.

[5] ТОВ «Полтавагаз збут» інформує споживачів природного газу щодо тарифів та ціни на природний газ для промислових споживачів та бюджетних організацій з 1 квітня 2019 p. URL: http://poltavagazzbut.com.ua/?page_ $\mathrm{id}=28$.

(C) Ганошенко О. М. Дата надходження статті до редакції: 25.06.2020 Дата затвердження статті до друку: 27.07.2020 